\title{
How Capsular Exopolysaccharides Affect Cell Surface Properties of Lactic Acid Bacteria
}

\author{
Carsten Nachtigall ${ }^{1, * \mathbb{D}}$, Cordula Vogel ${ }^{2} \mathbb{D}$, Harald Rohm ${ }^{1}$ and Doris Jaros ${ }^{1}$ \\ 1 Institute of Natural Materials Technology, Technische Universität Dresden, 01062 Dresden, Germany; \\ harald.rohm@tu-dresden.de (H.R.); doris.jaros@tu-dresden.de (D.J.) \\ 2 Institute of Soil Science and Site Ecology, Technische Universität Dresden, 01062 Dresden, Germany; \\ cordula.vogel@tu-dresden.de \\ * Correspondence: carsten.nachtigall@tu-dresden.de; Tel.: +49-351-463-38797
}

Received: 16 November 2020; Accepted: 27 November 2020; Published: 30 November 2020

\begin{abstract}
Some lactic acid bacteria are able to produce exopolysaccharides that, based on localization, can be distinguished in free and capsular or cell-bound exopolysaccharides (CPS). Up to now, the former were the focus of current research, mainly because of the technofunctional benefits they exhibit on fermented dairy products. On the other hand, CPS affect the surface properties of bacteria cells and thus also the textural properties of fermented foods, but data are very scarce. As the cell surface properties are strongly strain dependent, we present a new approach to investigate the impact of CPS on cell surface hydrophobicity and moisture load. CPS positive and negative Streptococcus thermophilus and Weissella cibaria were subjected to ultrasonication suitable to detach CPS without cell damage. The success of the method was verified by scanning electron and light microscopy as well as by cultivation experiments. Before applying ultrasonication cells with CPS exhibiting an increased hydrophilic character, enhanced moisture load, and faster water adsorption compared to the cells after CPS removal, emphasizing the importance of CPS on the textural properties of fermented products. The ultrasonic treatment did not alter the cell surface properties of the CPS negative strains.
\end{abstract}

Keywords: capsular exopolysaccharides; cell surface hydrophobicity; SEM; lactic acid bacteria; microbial adhesion to hydrocarbons (MATH); microscopy; moisture load; ruthenium tetroxide; Streptococcus thermophilus; ultrasound; Weissella cibaria

\section{Introduction}

The formation of exopolysaccharides is a widespread ability amongst lactic acid bacteria and is closely associated with texture-enhancing effects in fermented dairy products [1,2]. Gram-positive bacteria such as Streptococcus (hetero-fermentative) or Weissella (homo-fermentative) are able to produce exopolysaccharides that are then freely present in the fermentation medium. The underlying synthesis mechanisms, however, differ between the genera: while hetero-polysaccharides by Streptococcus thermophilus are synthesized inside the cell by the action of different glycosyltransferases (Wzx/Wzy-dependent pathway), homo-polysaccharides from Weissella cibaria (glucans or fructans) are produced extracellularly by the action of a single sucrase from sucrose as the only substrate [3-5]. In particular, hetero-polysaccharides exhibit a large variety in structure due to differences in monosaccharide composition (mainly glucose, galactose, rhamnose) and in their anomeric configuration, and in regard to functional groups, linkage type, branching, and side chain length [6]. Homo-polysaccharides mainly differ in their glycosidic linkages and degree of branching [7]. Improved water binding capacity, viscosity enhancement, and reduced syneresis of fermented products are only a few factors that have raised interest in microbial, in situ produced free exopolysaccharides and their possible ex situ application such as thickening agents or stabilizers in non-fermented foods [8-11]. 
In addition to the well-studied free exopolysaccharides, some strains are also able to synthesize exopolysaccharides that remain covalently attached to $\mathrm{N}$-acetylmuramic acid residues of the cell wall peptidoglycan; these are usually denoted as capsular or cell-bound exopolysaccharides (CPS) [5,11-13]. Generally, it is assumed that CPS contribute to adhesion, for instance, on solid surfaces or in food matrices, and to the associated formation of biofilms [14,15], to adhesion in the intestinal tract [16], or to stress protection (e.g., salt and acid stress) [17], and therefore affect the cell surface properties and interactions with the surrounding matrix [18]. A few studies have pointed out the improved properties of fermented dairy products, for example, increased water retention capacity and melting behavior of mozzarella with CPS forming S. thermophilus $[19,20]$ or of cheese with Lactobacillus helveticus or Lactococcus lactis [21-23]. Improved creaminess, enhanced textural properties and viscosity [24], and higher gel stiffness [25] were observed in acid gels. Hassan and Frank [26] reported that CPS improved the adhesion of E. coli cells to apple and lettuce surfaces, but no differences in electrostatic and hydrophobic interactions were found compared to CPS negative cells.

CPS are also important concerning the virulence of pathogenic microorganisms such as Erwinia stewartii, Erwinia amylovora or Xanthomonas campestris (corn pathogens) [27,28], Lactococcus garvieae (fish pathogen) [29], and E. coli K4, S. pneumoniae, or Salmonella enteriditis (human pathogens) [30,31], but the underlying mechanism is not always fully understood. In the case of salmonella, the presence of CPS induces a resistance of the cell surface against acids and bleaching agents [31]. The antibiotic resistance of $S$. pneumoniae can also be retraced to its CPS as antibiotics induce CPS to change the serotype by genetic recombination $[32,33]$. However, anti-CPS antibodies may be able to defend the host organism against pathogenic encapsulated bacteria [28]. Common measures for the characterization of the bacteria surface include cell surface hydrophobicity (CSH) as determined by the microbial adhesion to hydrocarbons (MATH) assay or by contact angle measurements, the zeta potential, or the moisture load $[15,34,35]$. Positive correlations were found between CSH and autoaggregation properties of propionibacteria [36], and between CSH and protein content of the cell surface of Lactobacillus rhamnosus [37]. The presence of polysaccharides at the cell surface resulted in a more hydrophilic character and lower CSH values [17,38,39]. In turn, cell surfaces without CPS showed higher CSH due to the increased amount of nonpolar protein side chains [11]. However, it has also been shown that $\mathrm{CSH}$ is variable over a wide range within genera and strongly strain-dependent. Furthermore, it depends on cultivation conditions such as medium composition or temperature and the state of cultivation [40-44]. This resulted in CSH values for S. thermophilus between 0.05 and $98 \%$, but the influence of CPS on CSH was not investigated [45-47].

It is known that CPS exhibit a significant impact on the texture properties of fermented foods, but, up to now, the influence of CPS on the cell surface and therefore on interactions in fermented products has only been studied by comparing CPS positive and negative strains [11,17]. This may be, however, criticized because of the strong strain dependency of the cell surface properties. This is why we followed a different approach in this study. The aim was to investigate the impact of CPS on cell surface hydrophobicity and moisture load before and after CPS detachment of different $S$. thermophilus and $W$. cibaria strains. For CPS removal from the cells, an ultrasonic treatment was used, and the ultrasound parameters (amplitude, sonication time) were chosen in a way that it did not affect the cell viability, which was verified by imaging methods and cultivation experiments.

\section{Materials and Methods}

\subsection{Materials}

S. thermophilus ST143+ and ST143- were provided by Christian Hansen A/S (Hørsholm, Denmark), S. thermophilus DGCC7984 by Danisco Deutschland GmbH (Niebüll, Germany), and W. cibaria DSM14295 by Deutsche Sammlung von Mikroorganismen und Zellkulturen GmbH (Braunschweig, Germany). All strains were stored as cryocultures at $-80^{\circ} \mathrm{C}$. Tryptone and n-hexadecane were purchased from Carl Roth GmbH \& Co. KG (Karlsruhe, Germany) and stored under oxygen-free conditions. Whey permeate 
powder was obtained by Wheyco $\mathrm{GmbH}$ (Altentreptow, Germany) and ruthenium tetroxide $\left(\mathrm{RuO}_{4}\right.$, $0.5 \%$ stabilized aqueous solution) by Polysciences Inc. (Warrington, FL, USA).

\subsection{Cultivation Conditions}

Cultivation of $S$. thermophilus was carried out in an enriched whey permeate medium, consisting of $60.0 \mathrm{~g} / \mathrm{L}$ whey permeate powder and $10.0 \mathrm{~g} / \mathrm{L}$ tryptone. W. cibaria was cultivated in whey permeate medium (100 g/L) enriched with $10.0 \mathrm{~g} / \mathrm{L}$ tryptone, $2 \mathrm{~g} / \mathrm{L}$ ammonium sulphate, $9.9 \mathrm{~g} / \mathrm{L}$ glucose monohydrate, and $34.2 \mathrm{~g} / \mathrm{L}$ sucrose. After inoculation, the pre-cultures were incubated for $24 \mathrm{~h}$ at $40{ }^{\circ} \mathrm{C}$ (S. thermophilus) or $37^{\circ} \mathrm{C}$ (W. cibaria) under anaerobic conditions $\left(10 \% \mathrm{H}_{2} ; 10 \% \mathrm{CO}_{2} ; 80 \% \mathrm{~N}_{2}\right.$ ). A total of $50 \mathrm{~mL}$ fresh medium was inoculated with $1 \%(v / v)$ pre-culture and incubated under anaerobic conditions for $16 \mathrm{~h}$ at $40{ }^{\circ} \mathrm{C}$ (S. thermophilus) or for $24 \mathrm{~h}$ at $25^{\circ} \mathrm{C}$ or $30^{\circ} \mathrm{C}$ (W. cibaria). The fermentation broth was then used immediately for further investigations or stored at $-80^{\circ} \mathrm{C}$. All cultivations were performed in duplicate.

\subsection{Optical Density of Cell Suspensions}

The optical density $\mathrm{OD}_{577}[-]$ was determined by measuring the turbidity of the cell suspensions at $577 \mathrm{~nm}$. For $\mathrm{OD}_{577}>0.4$ the suspensions were diluted, and turbidity was multiplied with the dilution factor. Cell-free supernatants, obtained by centrifugation $(14,100 \times g ; 5 \mathrm{~min}$; room temperature), were used as blanks.

\subsection{Determination of Bacteria Cell Chain Length}

The length of the $S$. thermophilus cell chains was derived from microscopic images (Axiostar microscope, Carl Zeiss Microscopy GmbH, Jena, Germany) at 1000-fold magnification with at least 200 cell chains per sample for statistical investigation. The images were processed with Fiji [48] and the resulting cell chain length distribution characterized by theoretical $\mathrm{x}_{10}, \mathrm{x}_{50}$ (median) and $\mathrm{x}_{90}$ values.

\subsection{Ultrasonication of Bacteria Cells}

To remove CPS from the bacteria cells, a $2 \mathrm{~mL}$ cell suspension was treated with a UDS751 ultrasound disintegrator (Topas $\mathrm{GmbH}$, Dresden, Germany), operating at $24 \mathrm{kHz}$ and at an amplitude of $100 \%$ for $18 \mathrm{~s}$ unless noted otherwise. During ultrasonication, the samples were cooled in an ice bath.

\subsection{Visualization of Capsular Exopolysaccharides}

\subsubsection{Light Microscopy}

The presence of CPS was visualized by negative ink staining [49]. Four $\mu \mathrm{L}$ of cell suspension was mixed with $6 \mu \mathrm{L}$ India ink on a glass slide and covered with a cover slip. Microscopic images were taken at 1000-fold magnification. As the ink is not able to permeate into the polysaccharide layer, CPS occur as a white zone around the cells.

\subsubsection{Scanning Electron Microscopy (SEM)}

To remove disturbing matrix substances, $2 \mathrm{~mL}$ of cell suspension was centrifuged $(14,100 \times g$; $5 \mathrm{~min}$; room temperature) and washed three times with $9.0 \mathrm{~g} / \mathrm{L}$ sodium chloride solution, and finally with deionized water. The cell pellets were fixated, stained, and freeze-dried for high-resolution images. Briefly, samples were fixed in $40 \mathrm{~g} / \mathrm{L}$ paraformaldehyde with $2 \%(v / v)$ glutaraldehyde in $0.1 \mathrm{~mol} / \mathrm{L}$ sodium cacodylate buffer for $45 \mathrm{~min}$. Subsequently, the samples were washed three times with $0.1 \mathrm{~mol} / \mathrm{L}$ sodium cacodylate buffer for $10 \mathrm{~min}$, and then stained with $0.5 \% \mathrm{RuO}_{4}$. The residual $\mathrm{RuO}_{4}$ was removed by washing five times in deionized water. After fixation and staining, the samples were frozen and subsequently freeze-dried. The dry cell material was fixed on aluminum specimen holders using conductive double-sided adhesive carbon tabs and coated with approximately $40 \mathrm{~nm}$ 
carbon, using an EMITECH K905 Carbon Coater (Emitech Ltd., Ashford, Kent, England). This was done to minimize charging effects and to allow better resolution, maintained under high vacuum.

Bacteria cells before and after ultrasonication were visualized with an environmental scanning electron microscope under high vacuum (Quanta FEG 650, Thermo Fisher Scientific, Waltham, MA, USA). Several images were gathered from each sample at $10 \mathrm{kV}$ beam energy and a spot size of 2.5 . The cell diameters of approx. 50 cells per sample were determined from SEM images using Fiji [48].

\subsection{Cell Surface Properties}

\subsubsection{Cell Surface Hydrophobicity}

Cell surface hydrophobicity was determined with the MATH test according to Rosenberg et al. [50] with some modifications [49]. Approx. $5 \mathrm{~mL}$ of a fresh cultured cell suspension were centrifuged $\left(19,000 \times \mathrm{g} ; 15 \mathrm{~min} ; 4^{\circ} \mathrm{C}\right)$ and the cell pellet washed twice with $9.0 \mathrm{~g} / \mathrm{L}$ sodium chloride solution. Subsequently, the cells were resuspended in phosphate buffered saline (PBS) buffer $(0.20 \mathrm{~g} / \mathrm{L}$ potassium chloride; $8.00 \mathrm{~g} / \mathrm{L}$ sodium chloride; $1.44 \mathrm{~g} / \mathrm{L}$ disodium hydrogen phosphate; $0.24 \mathrm{~g} / \mathrm{L}$ potassium dihydrogen phosphate; $\mathrm{pH} 7.4)$ and $\mathrm{OD}_{577}$ of the suspension adjusted to $0.4\left(\mathrm{~A}_{0}[-]\right)$. Three $\mathrm{mL}$ of suspension was transferred into glass test tubes, washed with $37 \%(v / v)$ hydrochloric acid for $10 \mathrm{~min}$ in an ultrasonic bath prior to use, and mixed thoroughly for $60 \mathrm{~s}$ with $0.3 \mathrm{~mL}$-hexadecane. As a blank, $3.0 \mathrm{~mL}$ of PBS buffer instead of cell suspension was used. The mixture was transferred into disposable polystyrene cuvettes and placed on a magnetic stirrer (Cimarec i Multipoint 15, Thermo Scientific, Waltham, MA, USA) for phase separation $\left(15 \mathrm{~min}, 25^{\circ} \mathrm{C}\right)$. The rotation speed was adjusted to prevent cell sedimentation, but without impeding phase separation. After $15 \mathrm{~min}$, the $\mathrm{OD}_{577}$ of the aqueous phase was read and designed as $\mathrm{A}_{1}[-]$ or $\mathrm{A}_{\text {blank }}[-]$. All determinations were performed in triplicate. $\mathrm{CSH}[\%]$ was calculated using Equation (1):

$$
\mathrm{CSH}=\frac{\mathrm{A}_{0}-\left(\mathrm{A}_{1}-\mathrm{A}_{\mathrm{blank}}\right)}{\mathrm{A}_{0}} \times 100
$$

\subsubsection{Moisture Load}

Cell suspensions were washed three times with deionized water to remove low-molecular substances, followed by freeze-drying. The moisture-free samples were stored in a desiccator over $\mathrm{P}_{2} \mathrm{O}_{5}$ until further use.

Moisture load was determined as described previously with some modifications [51]. An approx. $5 \mathrm{mg}$ sample was placed in a quartz crucible of a Q5000SA dynamic vapor sorption analyzer (TA instruments, New Castle, DE, USA). Relative humidity (RH) in the measuring chamber was set to $0 \%$ and incrementally increased to $98 \%$ (steps of $10 \%$, last step $8 \%$ ) unless noted otherwise. The mass was read throughout the analysis by the instrument's microbalance. Once one of the abort criteria (I) constant mass $(\leq 0.01 \%$ within $5 \mathrm{~min}$ ) or (II) time limit of $500 \mathrm{~min}$ without achieving equilibrium were met, the next $\mathrm{RH}$ condition was applied. The moisture load $\mathrm{X}\left[\mathrm{g} \mathrm{H}_{2} \mathrm{O} / \mathrm{g}\right.$ dry mass] at each $\mathrm{RH}$ level was calculated from the final equilibrium mass of each step. For a relative humidity of $0-80 \%$ and the respective water activities of $0.0 \leq \mathrm{a}_{\mathrm{w}} \leq 0.8(0 \%<\mathrm{RH}<80 \%)$, $\mathrm{X}$ was fitted into the Guggenheim-Anderson-De Boer (GAB) equation [52,53]:

$$
X=\frac{\mathrm{X}_{0} \cdot \mathrm{C}_{\mathrm{GAB}} \cdot \mathrm{k}_{\mathrm{GAB}} \cdot \mathrm{a}_{\mathrm{W}}}{\left(1-\mathrm{k}_{\mathrm{GAB}} \cdot \mathrm{a}_{\mathrm{W}}\right)\left(1-\mathrm{k}_{\mathrm{GAB}} \cdot \mathrm{a}_{\mathrm{W}}+\mathrm{C}_{\mathrm{GAB}} \cdot \mathrm{k}_{\mathrm{GAB}} \cdot \mathrm{a}_{\mathrm{W}}\right)}
$$

\subsection{Statistics}

All results are displayed as arithmetic mean \pm standard deviation. Differences were statistically tested with the multiple Tukey-Kramer test $(p<0.05)$ after performing one-way analysis of variance (ANOVA) using SPSS Statistics 25 (IBM, New York, NY, USA). 


\section{Results and Discussion}

\subsection{Visualization of Capsular Exopolysaccharides}

After contrast staining, S. thermophilus ST143+ and W. cibaria DSM14295 showed white zones around the cell chains and were thus classified as CPS producers (Figure 1a,c,e,g). S. thermophilus ST143- and DGCC7984 did not produce CPS and were used as negative controls.
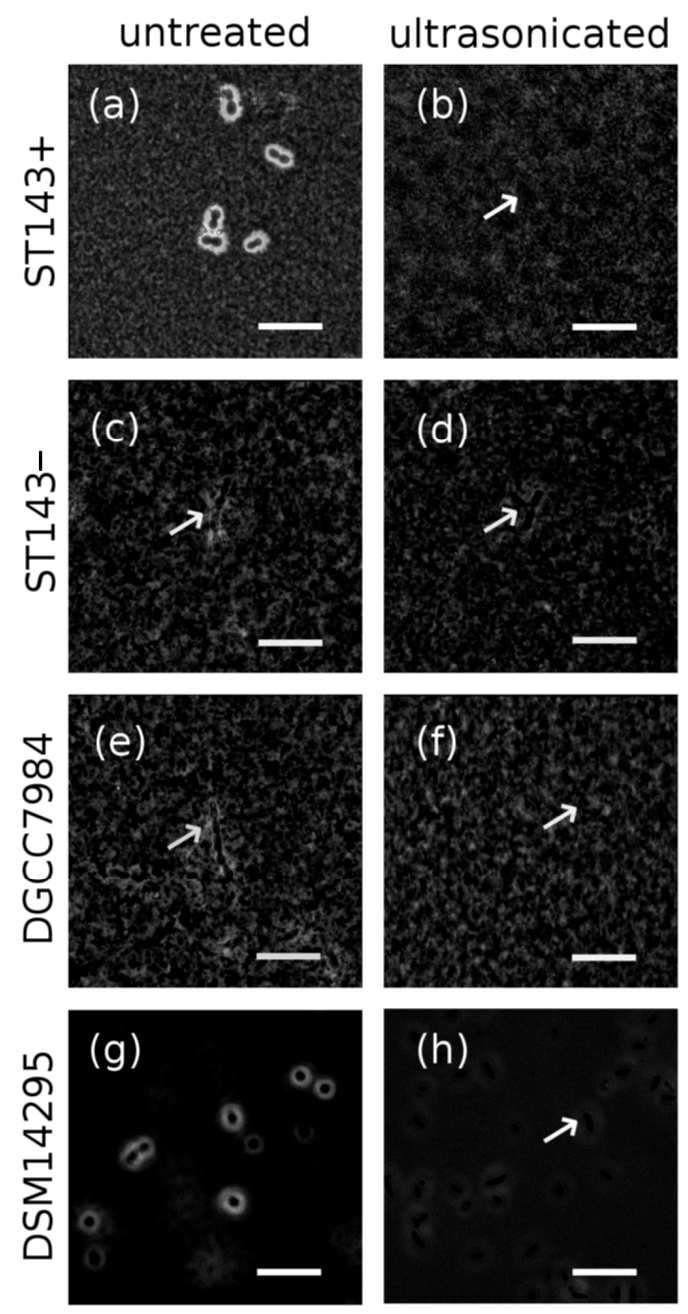

Figure 1. Microscopic images of the cell suspensions of $S$. thermophilus ST143+ (a,b), ST143- (c,d), DGCC7984 (e,f), and W. cibaria DSM14295 (g,h) stained with India ink for CPS visualization, before (left) and after (right) ultrasonic treatment for CPS removal. Magnification: 1000×, scale bar: $10 \mu \mathrm{m}$. Arrows indicate microbial cell chains.

Obtaining sufficient contrast is a challenge for the visualization of bacterial features by SEM. A poor contrast frequently arises from phases providing only small differences in electron density. This difficulty can be overcome by staining the hydrocarbon polymer phase with a heavy-atom-containing reagent such as osmium tetroxide $\left(\mathrm{OsO}_{4}\right)$ or ruthenium tetroxide $\left(\mathrm{RuO}_{4}\right)$, which we chose because of its lower toxicity [54]. In addition, $\mathrm{RuO}_{4}$ is supposed to react strongly with polar lipids, proteins, glycogen, and monosaccharides [55]. Joubert et al. [56] applied $\mathrm{RuO}_{4}$ for staining Aspergillus fumigatus biofilms and described it as an excellent contrasting agent for cellular and extracellular matrix components of the biofilm whereby, in contrast to $\mathrm{OsO}_{4}$, fibrous ultrastructures were resolved both on and between hyphae.

S. thermophilus ST143+ showed typical elongated ellipsoid-shaped cells, with the cover of CPS causing a rough, rugged surface (Figure 2a). The single cell chains tended to associate and aggregate as was also observed for CPS-producing Propionibacterium freudenreichii $[57,58]$. Structural features 
attributable to cell division were not visible because they were superimposed by the CPS layer. The free exopolysaccharides from ST143+ consist of a pentameric repeating unit build of 1,4-linked $\alpha$-/ $\beta$-glucose and $\beta$-galactose with 1,6-linked dimeric side chains [59]. We assumed that the CPS had the same structure as their synthesis pathway did not differ from that of the free exopolysaccharides. However, it is still not possible to predict the functionality (e.g., water binding, texture enhancement) of a specific EPS only from its structure. This is also true for CPS-covered cells in fermented foods [28].
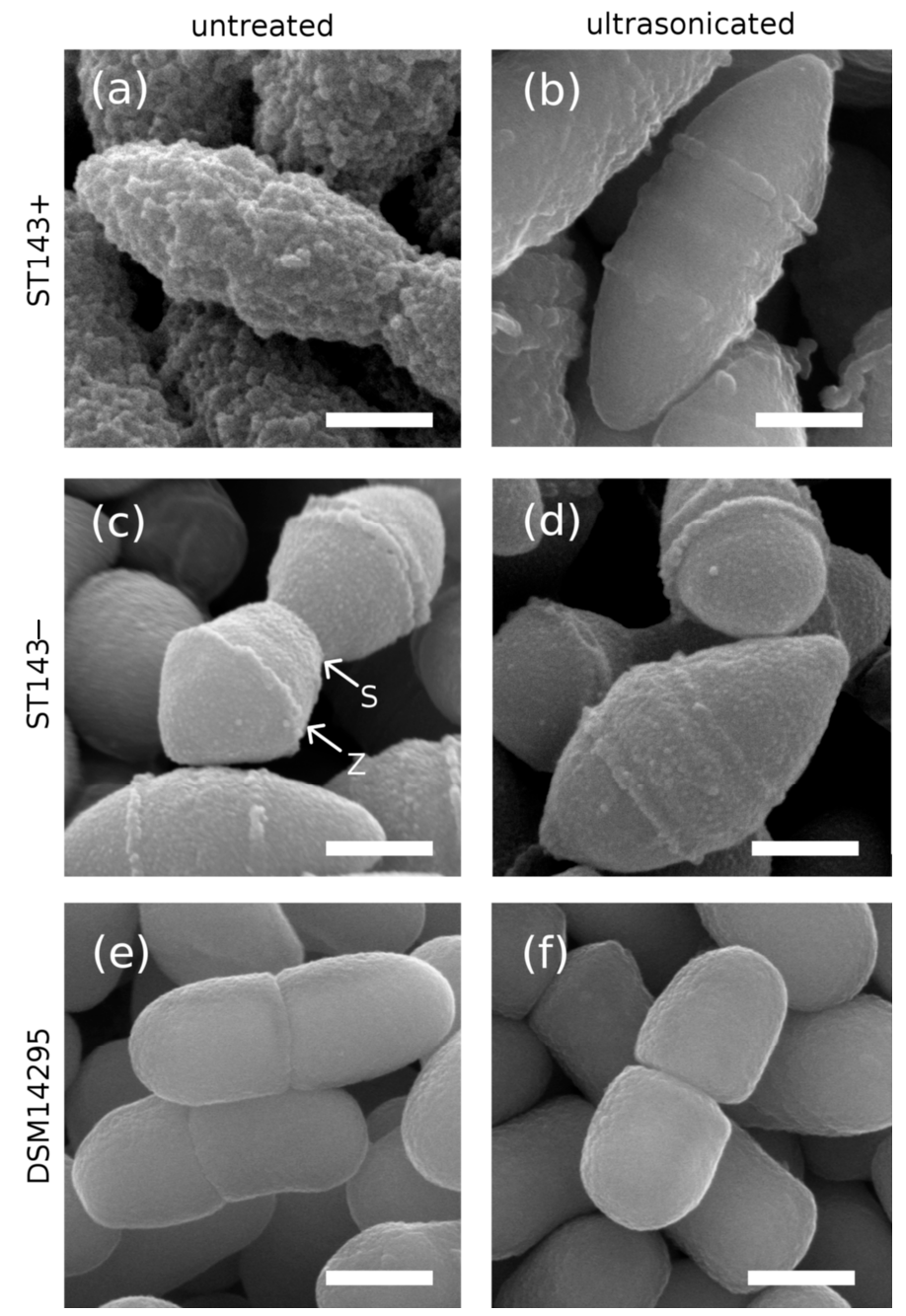

Figure 2. Comparison of the cells of S. thermophilus ST143+ (a,b), ST143- (c,d), and W. cibaria DSM14295 $(\mathbf{e}, \mathbf{f})$ before (left) and after (right) ultrasonic treatment for CPS removal as demonstrated by SEM images. Z: Z-ring; S: septum; scale bar: $500 \mathrm{~nm}$.

As ST143- does not produce any exopolysaccharides, its cell surface appeared smooth. Division septa (S) and Z-rings (Z) are proteinous structures responsible for cell division [60,61], and were clearly visible depending on the individual state of cell division (Figure 2c). Streptococci and Weissella cells divide in successive parallel planes perpendicular to their long axis that may lead, in the case of S. thermophilus, to elongated cell chains [62].

W. cibaria DSM14295 showed a more rectangular shape with visible division septa and a smooth surface (Figure 2e), suggesting a CPS-free cell surface in contrast to the white zones visible in light microscopy. W. cibaria is generally able to produce homo- and hetero-polysaccharides [12]. For DSM14295, the CPS synthesis pathway and the binding mechanism to the cell surface are, however, still unknown. As possible reasons for the smoother surface, we assumed that CPS are either attached more loosely to the cells and therefore lost during SEM sample preparation, or CPS exhibited a lower 
molecular mass compared to CPS from S. thermophilus (e.g., DGCC7710 CPS: $1.74 \times 10^{6}$ Da [63]) and were thus less entangled.

It was also possible to distinguish between cells with and without CPS according to their size in SEM images (ST143+: $0.84 \pm 0.04 \mu \mathrm{m}$; ST143-: $0.75 \pm 0.10 \mu \mathrm{m}$; cell diameter of their short axis). DSM14295 showed a cell diameter of $0.60 \pm 0.04 \mu \mathrm{m}$.

\subsection{Detachment of Capsular Exopolysaccharides from Bacteria Cells}

Different thermal, acoustical, and chemical methods for the detachment of CPS from the bacteria cell wall are described in the literature [1,64]. A heat treatment was not appropriate as it resulted in cell lysis, altering cell surface characteristics and interfering with the MATH assay [49]. Chemical treatments with, for example, sodium hydroxide, EDTA, or phenol, may lead to side reactions with cell wall constituents or to polysaccharide hydrolysis [65]. Ultrasonication is a widespread tool, for example, extraction of intracellular substances [66], reduction of yeasts and lactic acid bacteria as a non-thermal alternative [67], modification of polysaccharide properties [68,69], or the enhancement of the emulsification, fermentation, and sensory properties of fermented milk products [70]. This method is fast and easy-to-handle. The energy input can be controlled by amplitude and time, so cell lysis can also be avoided as suggested in the present study. Thus, different ultrasonication conditions were tested (amplitude: $60-100 \%$; time: $10 \mathrm{~s}-2 \mathrm{~min}$ ) to determine the lowest energy input necessary for CPS detachment from the cells.

For an amplitude $<100 \%$, CPS remained attached to the cells as was confirmed by microscopic images. Increased sonication times at $100 \%$ amplitude increased the amount of destroyed cells. The minimum time for removing CPS from the cells was $18 \mathrm{~s}$ and thus applied to all further experiments as no cell disruption was detected in the microscopic images (Figure $1 \mathrm{~b}, \mathrm{~d}, \mathrm{f}, \mathrm{h}$ ).

In the case of $S$. thermophilus strains, ultrasonication also reduced the cell chain length (Figure 3). This effect was most pronounced for ST143+ and DGCC7984, where the cell chains were shortened by 44 and $67 \%\left(x_{90}\right)$, respectively. DGCC7984 showed exceptionally long cell chains $\left(x_{90}=43.23\right)$ compared to ST143- $\left(x_{90}=3.20\right)$, where the treatment had only a small effect $\left(x_{90}=2.60\right.$ after ultrasonication $)$. The shortened cell chains were beneficial for a correct CSH determination, as the tendency of the bacteria cells to sediment during the MATH assay was reduced.
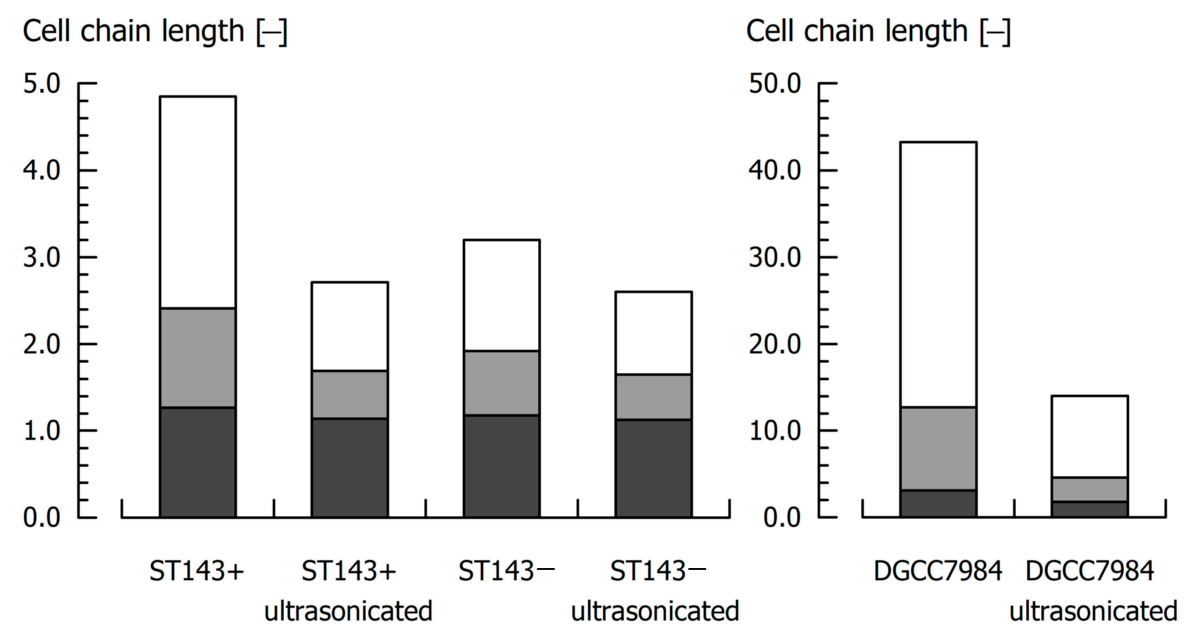

Figure 3. Bacteria cell chain length of $S$. thermophilus before and after ultrasonic treatment for CPS removal. Dark grey: $\mathrm{x}_{10}$; light grey: $\mathrm{x}_{50}$ (median); white: $\mathrm{x}_{90}$ values of the cell chain length distribution.

The morphological changes caused by CPS removal were also visible in the SEM images (Figure 2b,d,f). The cell surface of ultrasonicated ST143+ was smoother for the majority of the cells, and appeared similar to that of ST143-, apart from their different state of cell division. This also indicates that the CPS were successfully removed. No damage to the cell surface could be detected, 
and Z-rings were now clearly visible. No morphological changes were observed for ST143-. This was also true for DSM14295, which was, however, classified as a CPS producer. As already stated, the CPS of the untreated cells may have been lost during SEM sample preparation because of their different attachment to the cell wall compared to $S$. thermophilus cells.

The cell diameter of ST143+ was also significantly reduced by sonication $(0.72 \pm 0.05 \mu \mathrm{m})$. Under the assumption that CPS were not lost during $S$. thermophilus preparation, untreated ST143+ cells exhibited a CPS layer of approx. $120 \mathrm{~nm}$ that was one sixth of the cell diameter. For ST143- and DSM14295, no significant changes in the cell diameter $(0.76 \pm 0.03$ and $0.61 \pm 0.04 \mu \mathrm{m}$, respectively) were observed.

To check that cell viability was not impaired by ultrasonication, fresh medium was inoculated with sonicated cell suspensions $(1 \%(v / v))$ and incubated as stated above. Neither growth kinetics (acidification speed; $\mathrm{pH}$ and $\mathrm{OD}_{577}$ at the end of cultivation) nor the ability to produce CPS differed from that of cultures with untreated inocula (data not shown).

\subsection{Influence of Capsular Exopolysaccharides on Cell Surface Hydrophobicity}

For $S$. thermophilus, no distinction could be made between the CPS positive ST143+ $(\mathrm{CSH}=6.0 \%)$ and CPS negative ST143- $(\mathrm{CSH}=5.2 \%)$ (Figure 4). Furthermore, different cultivation temperatures did not affect the hydrophobicity of cells from $W$. cibaria DSM14295. CSH was $6.4 \%$ after cultivation at $25^{\circ} \mathrm{C}$ and $6.2 \%$ after cultivation at $30{ }^{\circ} \mathrm{C}$. CSH of DGCC7984 was highest $(9.4 \%)$ within the investigated strains. The results underline the strain dependency of cell surface properties, independent from CPS formation, as reported in the literature $[39,40]$. Particularly for ST143+ and ST143-, which exhibited similar CSH values despite their difference in CPS production, other structural specifics in the cell wall composition must be responsible. For $W$. confusa, a CSH of $27 \%$ was reported under similar MATH test conditions, making the strain-dependent differences even more obvious [71].

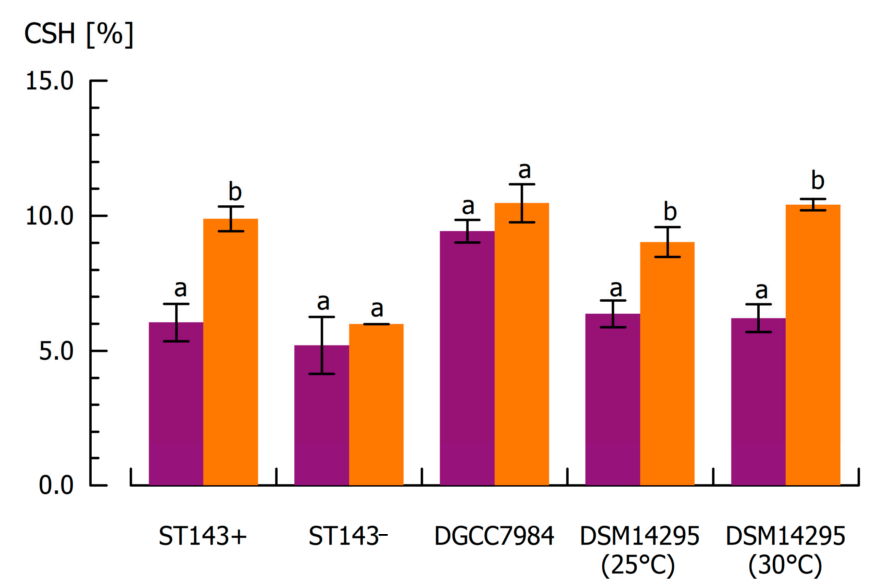

Figure 4. Cell surface hydrophobicity (CSH) of cells from S. thermophilus ST143+, ST143-, DGCC7984, and W. cibaria DSM14295 before (violet) and after ultrasonic treatment for CPS removal (orange). Mean values within the same strain with different superscripts differed significantly $(\alpha=0.05)$.

CSH of ST143+ increased significantly to 9.9\% after CPS detachment. This was also observed for DSM14295 independent from cultivation temperatures, whereas the CPS negative strains ST143- and DGCC7984 showed no sonication-induced changes in CSH. This clearly confirms that CPS provide a more hydrophilic character to the cell surface, and thus may have a significant impact on interactions with, for example, milk proteins in fermented dairy systems. Various studies reported that the presence of hydrophilic cell surfaces is associated with CPS, whereas proteins lead to a more hydrophobic surface $[11,17,37,38]$.

The ultrasonication of the CPS negative strains did not change the CSH, indicating that no destruction of the cells occurred, supporting our findings from SEM images. The MATH assay of re-cultivated, ultrasonicated cells resulted in similar values to those observed in the first assay; CSH was 
6.2 and $6.1 \%$ for ST143+ and ST143-, respectively, and thereby did not differ significantly from the $\mathrm{CSH}$ of untreated cultures (Figure 5, left). The same is true for ultrasonication of the re-cultivated cells: CSH increased for ST143+ (9.1\%) due to the detachment of CPS, but did not change significantly for ST143- (5.2\%).

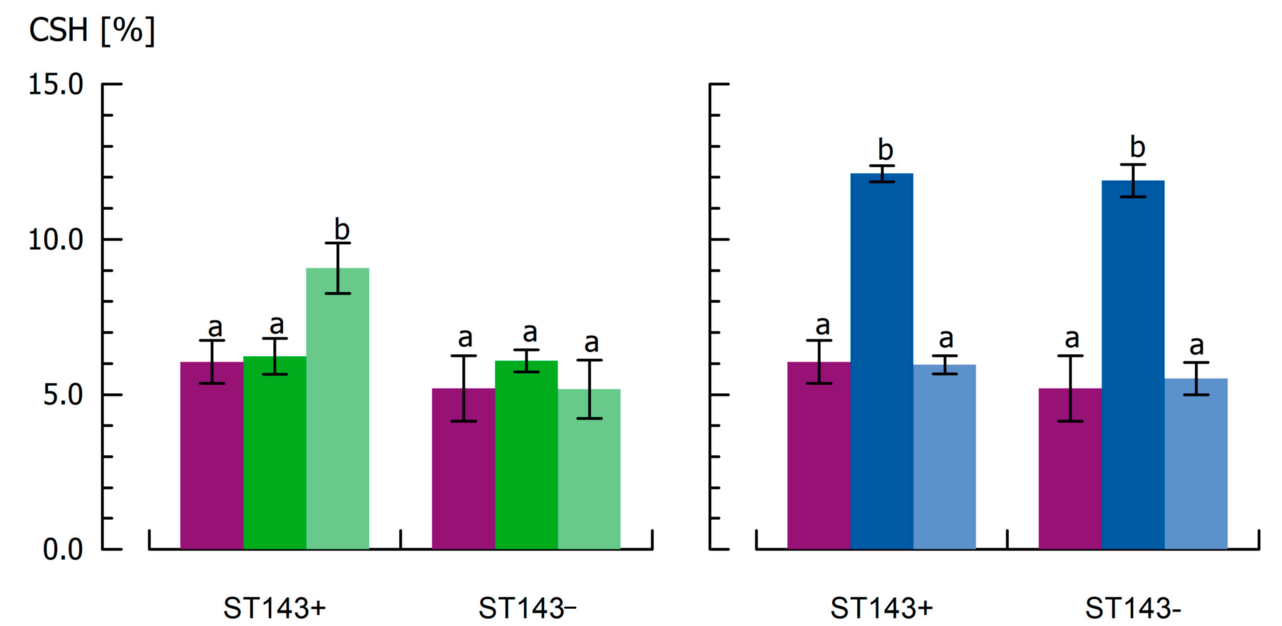

Figure 5. Cell surface hydrophobicity (CSH) of cells from S. thermophilus ST143+ and ST143- without further treatment (violet); (left) after ultrasonication + subsequent cultivation (dark green) and after ultrasonication + subsequent cultivation + second ultrasonication (light green); (right) after freeze drying (dark blue) and after freeze drying + subsequent cultivation (light blue). Mean values within the same strain with different superscripts differ significantly $(\alpha=0.05)$.

Freeze-drying, used for the preparation of cells for moisture sorption analysis, represents a physiological stress situation that, for instance, impairs membrane fluidity [72]. To check whether freeze-drying affects the cell surface properties, the MATH assay was also carried out on freeze-dried cells re-suspended in PBS buffer as well as on freeze-dried and subsequently re-cultivated cells (Figure 5, right). After freeze-drying, the cell surface was much more hydrophobic for both strains (CSH approx. 12\%). These findings seem consistent as the complete intra-cellular water was removed by freeze-drying. On the other hand, Selwal et al. [73] found similar CSH before and after freeze-drying of $S$. thermophilus cells. A subsequent fermentation with freeze-dried cells showed similar growth kinetics and $\mathrm{CSH}$ as untreated cells.

\subsection{Influence of Capsular Exopolysaccharides on Moisture Sorption}

With increasing $\mathrm{RH}$, the moisture sorption isotherms of freeze-dried S. thermophilus cells, without and with treatment for CPS removal, showed the sigmoid shape of type II isotherms after Brunauer et al. [74], typical for food and food-related samples and polysaccharides (Figure 6) [75-77]. The pronounced increase of equilibrium moisture load $\left(\mathrm{X}_{\mathrm{eq}}\right)$ at higher $\mathrm{RH}$ is linked to highly hygroscopic substances (e.g., mono- and polysaccharides or salts) [52]. For $\mathrm{RH} \leq 60 \%$, untreated and ultrasonicated cells showed similar adsorption isotherms. At higher $\mathrm{RH}$, the moisture load of untreated cells of $\mathrm{ST} 143+\left(\mathrm{X}_{90 \%}=0.337 \pm 0.003 \mathrm{~g} / \mathrm{g}\right)$ was $15 \%$ higher than for ST143+ without CPS. This indicates that CPS are crucial for moisture adsorption of bacteria cells. For CPS negative strains, the moisture load did not differ significantly between untreated and ultrasonicated cells, as $\mathrm{X}_{90 \%}$ was $0.299 \pm 0.007$ and $0.305 \pm 0.007 \mathrm{~g} / \mathrm{g}$ (ST143-) and $0.461 \pm 0.008$ and $0.477 \pm 0.010 \mathrm{~g} / \mathrm{g}$ (DGCC7984), respectively. This supports our previous findings that ultrasonication of CPS negative cells did not change their CSH. The results were confirmed by investigations on a CPS positive $S$. thermophilus DGCC7710. $\mathrm{X}_{90 \%}$ was significantly lower for cells without CPS (CPS were detached from the cells by heat treatment), and $\mathrm{X}_{90 \%}$ for untreated cells was in the same order of magnitude as isolated free exopolysaccharides and CPS of DGCC7710 [63]. However, as for CSH, we suppose that the strain dependent differences in absolute moisture load may be caused by differences in cell wall composition. It can be concluded that the 
detachment of CPS from the bacteria cells causes an increase in CSH that is accompanied by a reduction of the absorbable moisture.
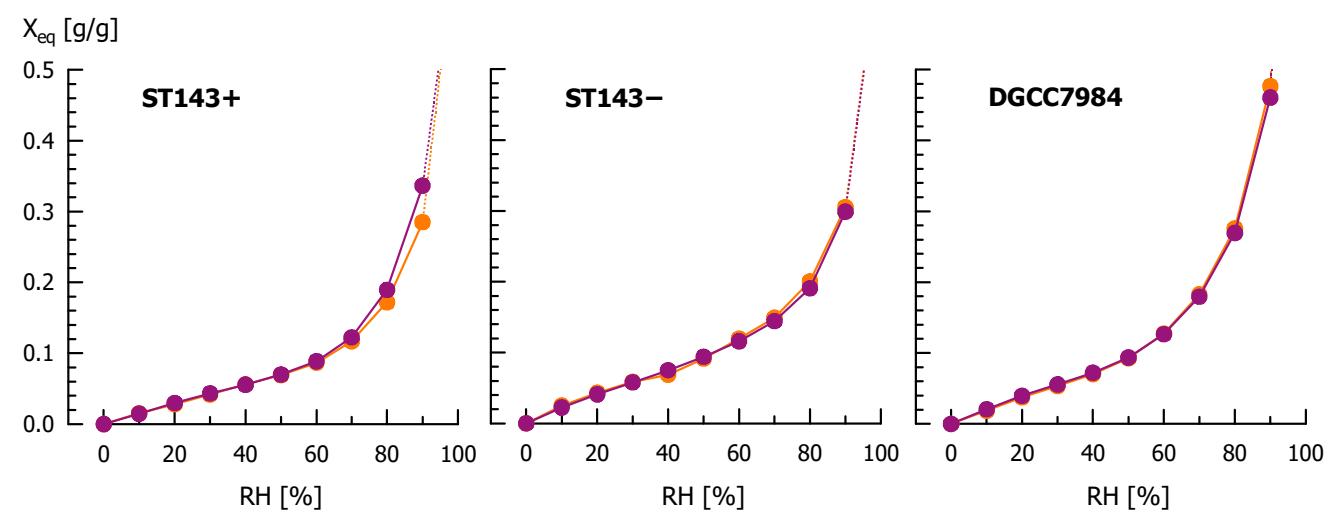

Figure 6. Equilibrium moisture load $\mathrm{X}_{\mathrm{eq}}$ [ $\mathrm{g} \mathrm{H}_{2} \mathrm{O} / \mathrm{g}$ dry matter] of $S$. thermophilus $\mathrm{ST} 143+$, $\mathrm{ST} 143-$ and DGCC7984 cells at different relative humidity (RH) levels, determined by dynamic vapor sorption analysis. Violet: untreated cells; orange: ultrasonicated cells.

The moisture load at different $\mathrm{RH}$ was also fitted into the GAB equation to obtain the adsorption isotherms (Equation (2); Table 1). At low RH, the cell surface is initially covered with a monolayer of water molecules expressed by $\mathrm{X}_{0}$. Although previous studies point to relationships between surface hydrophobicity and $X_{0}$ [78], this was not observed for the investigated S. thermophilus strains. The CPS negative strains ST143- and DGCC7984 had higher $X_{0}$ (0.070 and $0.058 \mathrm{~g} / \mathrm{g}$, respectively) than ST143+ $(0.044 \mathrm{~g} / \mathrm{g})$, and were in no case altered by sonication. The $\mathrm{k}_{\mathrm{GAB}}$ represents the chemical potential of free water $\left(k_{\mathrm{GAB}}=1.0\right)$ compared to the water bound in the multilayer of the sample [79]. High $\mathrm{k}_{\mathrm{GAB}}$ as observed in our study indicated low interactions between the bound water and sample surface. A low $\mathrm{C}_{\mathrm{GAB}}$ indicated that enthalpy differences between the free and bound water were small. Further dynamic vapor sorption experiments were performed where $\mathrm{RH}$, after achieving mass equilibrium at $\mathrm{RH}=0 \%$, was set directly to $98 \%$ (without time abort criterion). The time when $50 \%$ of the final moisture load $X_{98 \%}$ was adsorbed $\left(t_{1 / 2}\right.$ [min]) can be used to estimate the speed of moisture adsorption. For cells in native state, moisture adsorption was much faster for ST143+ (560 min) compared to ST143- (750 $\mathrm{min})$. This indicates that the transport of water into the cell (ST143-) takes more time than its adsorption at the hygroscopic CPS layer (ST143+). After ultrasonication, both strains showed an accelerated moisture adsorption (520 min for both strains) that may be attributed to the reduced cell chain length and possible changes in the cell wall composition at the former binding sites that were not detected with the previous analyses.

Table 1. Coefficients of the Guggenheim-Anderson-De Boer (GAB) adsorption isotherms $\mathrm{X}_{0, \mathrm{eq}}, \mathrm{C}_{\mathrm{GAB}}$, and $\mathrm{k}_{\mathrm{GAB}}$ for S. thermophilus ST143+, ST143-, and DGCC7984 cells without and with ultrasonic treatment for CPS removal.

\begin{tabular}{ccccc}
\hline & $\mathbf{X}_{\mathbf{0}, \mathbf{e q}}[\mathbf{g} / \mathbf{g}]$ & $\mathbf{C}_{\mathbf{G A B}}[-]$ & $\mathbf{k}_{\mathrm{GAB}}[-]$ & $\mathbf{r}^{\mathbf{2}}$ \\
\hline ST143+ & 0.044 & 4.728 & 0.967 & 0.999 \\
ST143+ (ultrasonicated) & 0.044 & 4.875 & 0.944 & 0.999 \\
ST143- & 0.058 & 6.881 & 0.900 & 0.999 \\
ST143- (ultrasonicated) & 0.060 & 6.202 & 0.899 & 0.999 \\
DGCC7984 & 0.070 & 3.056 & 0.952 & 0.999 \\
DGCC7984 (ultrasonicated) & 0.073 & 2.505 & 0.952 & 0.999 \\
\hline
\end{tabular}

\section{Conclusions}

The aim of this study was to evaluate the influence of CPS on the surface properties of lactic acid bacteria cells. To our knowledge, this is the first time that strain-dependent differences could 
be eliminated through the approach of using single strains and ultrasonication for CPS detachment. With CPS negative strains, we confirmed that the applied ultrasonication treatment did not affect growth kinetics, cell surface properties (hydrophobicity, moisture load), and morphology of the ultrasonicated cells. Light microscopy and SEM were suitable techniques to qualitatively distinguish between the CPS positive and negative strains. Using $\mathrm{RuO}_{4}$ as a staining agent allowed for the visualization of the CPS layer for S. thermophilus ST143+, which resulted in a significantly rougher cell surface than cells after CPS removal or CPS negative strains. The thickness of the CPS layer could be determined from the SEM images and was approx. $120 \mathrm{~nm}$. CPS increased the hydrophilic character of the cell surface (reduction of hydrophobicity from approx. 10\% to 6\%) and led to an increase in speed and the absolute amount of water adsorption of the cells (increase of $15 \%$ compared to cells after CPS detachment). This underlines the benefits that could be derived from CPS producing strains regarding, for example, texture, water binding capacity, or syneresis of fermented foods.

Author Contributions: C.N. and C.V. designed the experiments; C.N. and C.V. performed the experiments and analyzed the data; D.J. co-supervised the work; C.N., C.V., D.J., and H.R. wrote the manuscript. All authors have read and agreed to the published version of the manuscript.

Funding: This research was funded by Deutsche Forschungsgemeinschaft (Bonn, Germany), grant number JA2033/1-2.

Acknowledgments: We wish to thank Christian Hansen A/S and Danisco Germany for providing strains. The assistance of Carmen Weber and Tijana Kovanović in obtaining the data is gratefully acknowledged. Financial support was received from the SLUB/TU Dresden for Open Access publication.

Conflicts of Interest: The authors declare no conflict of interest.

\section{References}

1. Mende, S.; Rohm, H.; Jaros, D. Influence of exopolysaccharides on the structure, texture, stability and sensory properties of yoghurt and related products. Int. Dairy J. 2016, 52, 57-71. [CrossRef]

2. Zannini, E.; Waters, D.M.; Coffey, A.; Arendt, E.K. Production, properties, and industrial food application of lactic acid bacteria-derived exopolysaccharides. Appl. Microbiol. Biotechnol. 2016, 100, 1121-1135. [CrossRef] [PubMed]

3. De Vuyst, L.; DeGeest, B. Heteropolysaccharides from lactic acid bacteria. FEMS Microbiol. Rev. 1999, 23, 153-177. [CrossRef]

4. Van Hijum, S.A.F.T.; Kralj, S.; Ozimek, L.K.; Dijkhuizen, L.; Van Geel-Schutten, I.G.H. Structure-Function Relationships of Glucansucrase and Fructansucrase Enzymes from Lactic Acid Bacteria. Microbiol. Mol. Biol. Rev. 2006, 70, 157-176. [CrossRef] [PubMed]

5. Schmid, J. Recent insights in microbial exopolysaccharide biosynthesis and engineering strategies. Curr. Opin. Biotechnol. 2018, 53, 130-136. [CrossRef]

6. Zhou, Y.; Cui, Y.; Qu, X. Exopolysaccharides of lactic acid bacteria: Structure, bioactivity and associations: A review. Carbohydr. Polym. 2019, 207,317-332. [CrossRef]

7. Kavitake, D.; Devi, P.B.; Shetty, P.H. Overview of exopolysaccharides produced by Weissella genus-A review. Int. J. Biol. Macromol. 2020, 164, 2964-2973. [CrossRef]

8. Freitas, F.; Torres, C.A.V.; Reis, M.A.M. Engineering aspects of microbial exopolysaccharide production. Bioresour. Technol. 2017, 245, 1674-1683. [CrossRef]

9. Fusco, V.; Quero, G.M.; Cho, G.-S.; Kabisch, J.; Meske, D.; Neve, H.; Bockelmann, W.; Franz, C.M.A.P. The genus Weissella: Taxonomy, ecology and biotechnological potential. Front. Microbiol. 2015, 6, 155. [CrossRef]

10. Lynch, K.M.; Zannini, E.; Coffey, A.; Arendt, E.K. Lactic Acid Bacteria Exopolysaccharides in Foods and Beverages: Isolation, Properties, Characterization, and Health Benefits. Annu. Rev. Food Sci. Technol. 2018, 9 , 155-176. [CrossRef]

11. Zeidan, A.A.; Poulsen, V.K.; Janzen, T.; Buldo, P.; Derkx, P.M.F.; Øregaard, G.; Neves, A.R. Polysaccharide production by lactic acid bacteria: From genes to industrial applications. FEMS Microbiol. Rev. 2017, 41, S168-S200. [CrossRef] [PubMed] 
12. Malang, S.K.; Maina, N.H.; Schwab, C.; Tenkanen, M.; Lacroix, C. Characterization of exopolysaccharide and ropy capsular polysaccharide formation by Weissella. Food Microbiol. 2015, 46, 418-427. [CrossRef] [PubMed]

13. Ruas-Madiedo, P.; De Los Reyes-Gavilán, C.G. Invited Review: Methods for the Screening, Isolation, and Characterization of Exopolysaccharides Produced by Lactic Acid Bacteria. J. Dairy Sci. 2005, 88, 843-856. [CrossRef]

14. Boks, N.P.; Norde, W.; Van Der Mei, H.C.; Busscher, H.J. Forces involved in bacterial adhesion to hydrophilic and hydrophobic surfaces. Microbiology 2008, 154, 3122-3133. [CrossRef]

15. Ly, M.H.; Aguedo, M.; Goudot, S.; Le, M.L.; Cayot, P.; Teixeira, J.A.; Le, T.M.; Belin, J.-M.; Waché, Y. Interactions between bacterial surfaces and milk proteins, impact on food emulsions stability. Food Hydrocoll. 2008, 22, 742-751. [CrossRef]

16. Ruas-Madiedo, P.; Gueimonde, M.; Margolles, A.; de los LosReyes-Gavilán, C.G.; Salminen, S. Exopolysaccharides Produced by Probiotic Strains Modify the Adhesion of Probiotics and Enteropathogens to Human Intestinal Mucus. J. Food Prot. 2006, 69, 2011-2015. [CrossRef]

17. Dertli, E.; Mayer, M.J.; Narbad, A. Impact of the exopolysaccharide layer on biofilms, adhesion and resistance to stress in Lactobacillus johnsonii FI9785. BMC Microbiol. 2015, 15, 8. [CrossRef]

18. Hazen, K.C.; Plotkin, B.J.; Klimas, D.M. Influence of growth conditions on cell surface hydrophobicity of Candida albicans and Candida glabrata. Infect. Immun. 1986, 54, 269-271. [CrossRef]

19. Broadbent, J.R.; McMahon, D.J.; Oberg, C.J.; Welker, D.L. Use of exopolysaccharide-producing cultures to improve the functionality of low fat cheese. Int. Dairy J. 2001, 11, 433-439. [CrossRef]

20. Petersen, B.L.; Dave, R.I.; McMahon, D.J.; Oberg, C.J.; Broadbent, J.R. Influence of Capsular and Ropy Exopolysaccharide-Producing Streptococcus thermophilus on Mozzarella Cheese and Cheese Whey. J. Dairy Sci. 2000, 83, 1952-1956. [CrossRef]

21. Costa, N.E.; O'Callaghan, D.J.; Mateo, M.J.; Chaurin, V.; Castillo, M.; Hannon, J.A.; McSweeney, P.L.H.; Beresford, T.P. Influence of an exopolysaccharide produced by a starter on milk coagulation and curd syneresis. Int. Dairy J. 2012, 22, 48-57. [CrossRef]

22. Dabour, N.; Kheadr, E.; Benhamou, N.; Fliss, I.; Lapointe, G. Improvement of Texture and Structure of Reduced-Fat Cheddar Cheese by Exopolysaccharide-Producing Lactococci. J. Dairy Sci. 2006, 89, 95-110. [CrossRef]

23. Şanli, T.; Gursel, A.; Şanli, E.; Acar, E.; Benli, M. The effect of using an exopolysaccharide-producing culture on the physicochemical properties of low-fat and reduced-fat Kasar cheeses. Int. J. Dairy Technol. 2013, 66, 535-542. [CrossRef]

24. Folkenberg, D.M.; Dejmek, P.; Skriver, A.; Skov Guldager, H.; Ipsen, R. Sensory and rheological screening of exopolysaccharide producing strains of bacterial yoghurt cultures. Int. Dairy J. 2006, 16, 111-118. [CrossRef]

25. Surber, G.; Mende, S.; Jaros, D.; Rohm, H. Clustering of Streptococcus thermophilus strains to establish a relation between exopolysaccharide characteristics and gel properties of acidified milk. Foods 2019, 8, 146. [CrossRef]

26. Hassan, A.N.; Frank, J.F. Attachment of Escherichia coli O157:H7 grown in tryptic soy broth and nutrient broth to apple and lettuce surfaces as related to cell hydrophobicity, surface charge, and capsule production. Int. J. Food Microbiol. 2004, 96, 103-109. [CrossRef]

27. Nimtz, M.; Mort, A.; Domke, T.; Wray, V.; Zhang, Y.; Qiu, F.; Coplin, D.; Geider, K. Structure of amylovoran, the capsular exopolysaccharide from the fire blight pathogen Erwinia amylovora. Carbohydr. Res. 1996, 287, 59-76. [CrossRef]

28. Whitfield, C.; Wear, S.S.; Sande, C. Assembly of Bacterial Capsular Polysaccharides and Exopolysaccharides. Annu. Rev. Microbiol. 2020, 74, 521-543. [CrossRef]

29. Morita, H.; Toh, H.; Oshima, K.; Yoshizaki, M.; Kawanishi, M.; Suzuki, T.; Miyauchi, E.; Ishii, Y.; Tanabe, S.; Murakami, M. Complete Genome Sequence and Comparative Analysis of the Fish Pathogen Lactococcus garvieae. PLoS ONE 2011, 6, e23184. [CrossRef]

30. Cimini, D.; Restaino, O.F.; Catapano, A.; De Rosa, M.; Schiraldi, C. Production of capsular polysaccharide from Escherichia coli K4 for biotechnological applications. Appl. Microbiol. Biotechnol. 2010, 85, 1779-1787. [CrossRef]

31. Snyder, D.S.; Gibson, D.; Heiss, C.; Kay, W.; Azadi, P. Structure of a capsular polysaccharide isolated from Salmonella enteritidis. Carbohydr. Res. 2006, 341, 2388-2397. [CrossRef] [PubMed] 
32. Bhatty, M.; Pruett, S.; Swiatlo, E.; Nanduri, B. Alcohol abuse and Streptococcus pneumoniae infections: Consideration of virulence factors and impaired immune responses. Alcohol 2011, 45, 523-539. [CrossRef] [PubMed]

33. Petersen, B.O.; Meier, S.; Paulsen, B.S.; Redondo, A.R.; Skovsted, I.C. Determination of native capsular polysaccharide structures of Streptococcus pneumoniae serotypes 39,42, and 47F and comparison to genetically or serologically related strains. Carbohydr. Res. 2014, 395, 38-46. [CrossRef] [PubMed]

34. Rosenberg, M. Adhesion to hydrocarbons and microbial hydrophobicity-Do the MATH. FEMS Microbiol. Lett. 2017, 364. [CrossRef]

35. Syamaladevi, R.M.; Tang, J.; Zhong, Q. Water Diffusion from a Bacterial Cell in Low-Moisture Foods. J. Food Sci. 2016, 81, R2129-R2134. [CrossRef]

36. Darilmaz, D.O.; Beyatli, Y. Investigating Hydrophobicity and the Effect of Exopolysaccharide on Aggregation Properties of Dairy Propionibacteria Isolated from Turkish Homemade Cheeses. J. Food Prot. 2012, 75, 359-365. [CrossRef] [PubMed]

37. Deepika, G.; Green, R.J.; Frazier, R.A.; Charalampopoulos, D. Effect of growth time on the surface and adhesion properties of Lactobacillus rhamnosus GG. J. Appl. Microbiol. 2009, 107, 1230-1240. [CrossRef] [PubMed]

38. Daffonchio, D.; Thaveesri, J.; Verstraete, W. Contact angle measurement and cell hydrophobicity of granular sludge from upflow anaerobic sludge bed reactors. Appl. Environ. Microbiol. 1995, 61, 3676-3680. [CrossRef]

39. Petrova, P.; Tsvetanova, F.; Petrov, K. Low cell surface hydrophobicity is one of the key factors for high butanol tolerance of Lactic acid bacteria. Eng. Life Sci. 2019, 19, 133-142. [CrossRef]

40. Flint, S.H.; Brooks, J.D.; Bremer, P.J. The influence of cell surface properties of thermophilic streptococci on attachment to stainlesssteel. J. Appl. Microbiol. 1997, 83, 508-517. [CrossRef]

41. Lv, J.L.; Zhao, W.J. Analysis of the Cell Surface Hydrophobicity of Yoghurt Fermentation Bacteria. Adv. Mater. Res. 2011, 361, 1274-1278. [CrossRef]

42. Heravi, R.M.; KerManshahi, H.; Sankian, M.; Nassiri, M.R.; Moussavi, A.H.; Nasiraii, L.R.; Varasteh, A.R. Screening of lactobacilli bacteria isolated from gastrointestinal tract of broiler chickens for their use as probiotic. Afr. J. Microbiol. Res. 2011, 5, 1858-1868. [CrossRef]

43. Schr-Zammaretti, P.; Dillmann, M.-L.; D’Amico, N.; Affolter, M.; Ubbink, J. Influence of Fermentation Medium Composition on Physicochemical Surface Properties of Lactobacillus acidophilus. Appl. Environ. Microbiol. 2005, 71, 8165-8173. [CrossRef] [PubMed]

44. Tarazanova, M.; Huppertz, T.; Beerthuyzen, M.; Van Schalkwijk, S.; Janssen, P.; Wels, M.; Kok, J.; Bachmann, H. Cell Surface Properties of Lactococcus lactis Reveal Milk Protein Binding Specifically Evolved in Dairy Isolates. Front. Microbiol. 2017, 8, 1691. [CrossRef]

45. Couvigny, B.; Thérial, C.; Gautier, C.; Renault, P.; Briandet, R.; Guédon, E. Streptococcus thermophilus Biofilm Formation: A Remnant Trait of Ancestral Commensal Life? PLoS ONE 2015, 10, e0128099. [CrossRef]

46. Tuncer, B.Ö.; Tuncer, Y. Exopolysaccharide producer Streptococcus thermophilus ST8.01 strain; a potential probiotic culture. GIDA J. Food 2014, 39, 195-202.

47. Zhao, D.; Shah, N.P. Effect of tea extract on lactic acid bacterial growth, their cell surface characteristics and isoflavone bioconversion during soymilk fermentation. Food Res. Int. 2014, 62, 877-885. [CrossRef]

48. Schindelin, J.; Arganda-Carreras, I.; Frise, E.; Kaynig, V.; Longair, M.; Pietzsch, T.; Preibisch, S.; Rueden, C.; Saalfeld, S.; Schmid, B.; et al. Fiji: An open-source platform for biological-image analysis. Nat. Methods 2012, 9, 676-682. [CrossRef]

49. Nachtigall, C.; Weber, C.; Rothenburger, S.; Jaros, D.; Rohm, H. Test parameters and cell chain length of Streptococcus thermophilus affect the microbial adhesion to hydrocarbons assay: A methodical approach. FEMS Microbiol. Lett. 2019, 366, fnz150. [CrossRef]

50. Rosenberg, M.; Gutnick, D.; Rosenberg, E. Adherence of bacteria to hydrocarbons: A simple method for measuring cell-surface hydrophobicity. FEMS Microbiol. Lett. 1980, 9, 29-33. [CrossRef]

51. Nachtigall, C.; Berger, C.; Kovanović, T.; Wefers, D.; Jaros, D.; Rohm, H. Shear induced molecular changes of exopolysaccharides from lactic acid bacteria. Food Hydrocoll. 2019, 97, 105181. [CrossRef]

52. Al-Muhtaseb, A.H.; McMinn, W.A.M.; Magee, T.R.A. Moisture Sorption Isotherm Characteristics of Food Products: A Review. Food Bioprod. Process. 2002, 80, 118-128. [CrossRef]

53. Timmermann, E.O. Multilayer sorption parameters: BET or GAB values? Colloids Surf. A Physicochem. Eng. Asp. 2003, 220, 235-260. [CrossRef] 
54. Berkowitz, L.M.; Rylander, P.N. Use of Ruthenium Tetroxide as a Multi-purpose Oxidant. J. Am. Chem. Soc. 1958, 80, 6682-6684. [CrossRef]

55. Gaylarde, P.; Sarkany, I. Ruthenium Tetroxide for Fixing and Staining Cytoplasmic Membranes. Science 1968, 161, 1157-1158. [CrossRef]

56. Joubert, L.-M.; Ferreira, J.A.; Stevens, D.A.; Nazik, H.; Cegelski, L. Visualization of Aspergillus fumigatus biofilms with Scanning Electron Microscopy and Variable Pressure-Scanning Electron Microscopy: A comparison of processing techniques. J. Microbiol. Methods 2017, 132, 46-55. [CrossRef]

57. Belgrano, F.D.S.; Verçoza, B.R.F.; Rodrigues, J.C.F.; Hatti-Kaul, R.; Pereira, N. EPS production by Propionibacterium freudenreichii facilitates its immobilization for propionic acid production. J. Appl. Microbiol. 2018, 125, 480-489. [CrossRef]

58. Hammerschmidt, S.; Wolff, S.; Hocke, A.; Rosseau, S.; Müller, E.; Rohde, M. Illustration of Pneumococcal Polysaccharide Capsule during Adherence and Invasion of Epithelial Cells. Infect. Immun. 2005, 73, 4653-4667. [CrossRef]

59. Pachekrepapol, U.; Lucey, J.A.; Gong, Y.; Naran, R.; Azadi, P. Corrigendum to "Characterization of the chemical structures and physical properties of exopolysaccharides produced by various Streptococcus thermophilus strains" (J. Dairy Sci. 100:3424-3435). J. Dairy Sci. 2018, 101, 5668. [CrossRef]

60. Evans, K.; Stone, V.; Chen, L.; Ge, X.; Xu, P. Systematic study of genes influencing cellular chain length in Streptococcus sanguinis. Microbiology 2014, 160, 307-315. [CrossRef]

61. Weiss, D.S. Bacterial cell division and the septal ring. Mol. Microbiol. 2004, 54, 588-597. [CrossRef] [PubMed]

62. Zapun, A.; Vernet, T.; Pinho, M.G. The different shapes of cocci. FEMS Microbiol. Rev. 2008, 32, 345-360. [CrossRef] [PubMed]

63. Nachtigall, C.; Surber, G.; Bulla, J.; Rohm, H.; Jaros, D. Pilot scale isolation of exopolysaccharides from Streptococcus thermophilus DGCC7710: Impact of methodical details on macromolecular properties and technofunctionality. Eng. Life Sci. 2020, accepted.

64. Leroy, F.; De Vuyst, L. Advances in production and simplified methods for recovery and quantification of exopolysaccharides for applications in food and health. J. Dairy Sci. 2016, 99, 3229-3238. [CrossRef]

65. Wang, K.; Li, W.; Rui, X.; Chen, X.; Jiang, M.; Dong, M. Characterization of a novel exopolysaccharide with antitumor activity from Lactobacillus plantarum 70810. Int. J. Biol. Macromol. 2014, 63, 133-139. [CrossRef]

66. Geciova, J.; Bury, D.; Jelen, P. Methods for disruption of microbial cells for potential use in the dairy industry-A review. Int. Dairy J. 2002, 12, 541-553. [CrossRef]

67. Gracin, L.; Jambrak, A.R.; Juretić, H.; Dobrović, S.; Barukčić, I.; Grozdanović, M.; Smoljanić, G. Influence of high power ultrasound on Brettanomyces and lactic acid bacteria in wine in continuous flow treatment. Appl. Acoust. 2016, 103, 143-147. [CrossRef]

68. Li, J.; Li, B.; Geng, P.; Song, A.-X.; Wu, J.-Y. Ultrasonic degradation kinetics and rheological profiles of a food polysaccharide (konjac glucomannan) in water. Food Hydrocoll. 2017, 70, 14-19. [CrossRef]

69. Wu, T.; Zivanovic, S.; Hayes, D.G.; Weiss, J. Efficient Reduction of Chitosan Molecular Weight by High-Intensity Ultrasound: Underlying Mechanism and Effect of Process Parameters. J. Agric. Food Chem. 2008, 56, 5112-5119. [CrossRef]

70. Abesinghe, A.M.N.L.; Islam, N.; Vidanarachchi, J.K.; Prakash, S.; Silva, K.F.S.T.; Karim, M.A. Effects of ultrasound on the fermentation profile of fermented milk products incorporated with lactic acid bacteria. Int. Dairy J. 2019, 90, 1-14. [CrossRef]

71. Adesulu-Dahunsi, A.T.; Sanni, A.I.; Jeyaram, K.; Ojediran, J.O.; Ogunsakin, A.O.; Banwo, K. Extracellular polysaccharide from Weissella confusa OF126: Production, optimization, and characterization. Int. J. Biol. Macromol. 2018, 111, 514-525. [CrossRef] [PubMed]

72. De Angelis, M.; Gobbetti, M. Environmental stress responses in Lactobacillus: A review. Proteomics 2004, 4, 106-122. [CrossRef] [PubMed]

73. Selwal, K.K.; Selwal, M.K.; Gandhi, D.N. Effect of freeze drying process on some properties of Streptococcus thermophilus isolated from dairy products. Braz. J. Microbiol. 2011, 42, 1500-1505. [CrossRef] [PubMed]

74. Brunauer, S.; Deming, L.S.; Deming, W.E.; Teller, E. On a Theory of the van der Waals Adsorption of Gases. J. Am. Chem. Soc. 1940, 62, 1723-1732. [CrossRef]

75. Hernández, H.G.; Livings, S.; Aguilera, J.M.; Chiralt, A. Phase transitions of dairy proteins, dextrans and their mixtures as a function of water interactions. Food Hydrocoll. 2011, 25, 1311-1318. [CrossRef] 
76. Mutungi, C.; Schuldt, S.; Onyango, C.; Schneider, Y.; Jaros, D.; Rohm, H. Dynamic Moisture Sorption Characteristics of Enzyme-Resistant Recrystallized Cassava Starch. Biomacromolecules 2011, 12, 660-671. [CrossRef] [PubMed]

77. Torres, M.D.; Moreira, R.; Chenlo, F.; Vázquez, M.J. Water adsorption isotherms of carboxymethyl cellulose, guar, locust bean, tragacanth and xanthan gums. Carbohydr. Polym. 2012, 89, 592-598. [CrossRef]

78. Roman-Gutierrez, A.D.; Guilbert, S.; Cuq, B. Distribution of Water between Wheat Flour Components: A Dynamic Water Vapour Adsorption Study. J. Cereal Sci. 2002, 36, 347-355. [CrossRef]

79. Lewicki, P.P. The applicability of the GAB model to food water sorption isotherms. Int. J. Food Sci. Technol. 1997, 32, 553-557. [CrossRef]

Publisher's Note: MDPI stays neutral with regard to jurisdictional claims in published maps and institutional affiliations.

(C) 2020 by the authors. Licensee MDPI, Basel, Switzerland. This article is an open access article distributed under the terms and conditions of the Creative Commons Attribution (CC BY) license (http://creativecommons.org/licenses/by/4.0/). 